\title{
Negotiating Real Space and Real Time in Red Jacket: A Novel
}

\author{
Pamela C. Mordecai \\ Independent Scholar \\ pammordecai@gmail.com
}

\begin{abstract}
Writing about Ted Hughes and Emily Dickinson, Lissa Paul refers to a rebuttal Hughes wrote to a review by Eric Griffiths, in The Times, when Hughes "...tries to explain to Griffiths that, unlike school-based academic critics, he reads Shakespeare's plays 'from the more practical standpoint of one who constantly dismantles them...examining their arts like an industrial spy..."” [Paul's reply to review by Eric Griffiths, The Times, 01 April 1994, p. 5] Paul remarks: "In other words, a book of trade secrets" (Paul, 2001, p. 37). In writing this paper, I too am exposing secrets - plus it's bizarre to spy on one's own work. Nevertheless, I enjoyed poking around in Red Jacket: I'm some fifteen years from the novel, so there's some distance between it and me.
\end{abstract}

To summarize the story: the Carpenter family adopts Grace as a baby because her father, Ralston, rapes her mother, Phyllis (his half-sister), who is only twelve at the time. Ralston dies in suspicious circumstances shortly after. Phyllis's grandmother, Evadne, takes her from St. Chris, the small (imaginary), Caribbean island where they live, to join her mother, Daphne, in New York. Because Grace, who doesn't know she's adopted, is "red" while the Carpenters are "good and black," unkind people in the small plantation village where the Carpenters live, taunt her with being a 'jacket', that is, a child who has a different father from that of her siblings. However, encouraged by her adoptive grandfather, Gramps, she studies hard and wins scholarships, first to a prestigious high school in Queenstown, the capital, then to the University of Toronto (hereafter $\mathrm{U}$ of T), where she does brilliantly.

While at university, Grace finds out about her birth mother when she goes home to visit an ailing Gramps. She phones Phyllis on her return to Toronto. Phyllis joins her when she graduates from $\mathrm{U}$ of $\mathrm{T}$, the only family present, and they have a fuss. Grace arrives at grad school at the University of Michigan, only to get a letter telling her that Phyllis has had a major stroke, for which she immediately feels responsible.

When clients start arriving with strange symptoms at a shelter at which she volunteers (HIV/AIDS has started to spread in the US), Grace gets the job of identifying the disease.

Grace returns to the $\mathrm{U}$ of the Antilles (UA) in St. Chris to teach and do research for her $\mathrm{PhD}$. There she meets Mark Blackman, Dean of the Social Sciences faculty. Although he tries to dissuade her when she resigns abruptly, he does so only as a good head of department, not a friend, for they do not get to know each other especially well. In the course of doing research, she meets Charlie, her brother Edgar's roommate. Charlie helps her with statistics, in which he is an expert, and they fall in love. When she gets her degree, she goes to work with him in Haiti. One morning he leaves home (they live together) for work and she never sees him again.

Many years later, when she is a bureaucrat working at the WHO, she is sent to Mabuli, a small (imaginary) West African country, to examine the centre's set-up by a Jesuit priest, Jimmy Atule, to treat and educate people with HIV/AIDS. Atule is a widower and a trained midwife

Cultural and Pedagogical Inquiry, Summer 2020, 12(1), pp. 281-295

ISSN 1916-3460 (C) 2020 University of Alberta

http://ejournals.library.ualberta.ca/index.php/cpi/index 
unnerved by occasional, traumatic, clairvoyant fits. Just before Grace goes to Africa, she encounters Mark Blackman at a workshop. Now married, though (according to him) estranged from his wife, he runs an international development bank; he is also Chancellor of UA. They make love at a weekend workshop and when she arrives in Mabuli, she is pregnant, though she does not know. When she almost loses the baby, Atule looks after her and they become friends of a sort. She returns to Geneva and has the baby, a boy, she names Jeremiah. Mark, his father, knows nothing about the child, although both Jimmy and Phyllis, whom Grace asks to come to Geneva to take care of the child, advise Grace to tell Mark about him.

Jimmy and Grace become even closer, working together on a pilot project to stem the spread of HIV/AIDS in Sub-Saharan Africa. The story comes to a climax when Grace goes to St. Chris to receive a prestigious award from UA and falls gravely ill. Mark's wife, Mona (who has long since found out about Mark and Grace, has met Phyllis and gotten to know Jeremiah in Geneva), is in St. Chris for the ceremony. Jimmy foresees Grace's life-threatening illness and arranges for Phyllis and Jeremiah to fly with him to St. Chris to try to save her. As for the rest? Buy a copy of Red Jacket!

"Once upon a time in a country far away, there lived a..." Characters, like babies, need a womb space (place) and a gestation period (time) in which to develop. If it is the essence of story that characters change, they must exist in time, and unless disembodied, they must also exist in space. Thus we say stories have a setting, a place or places in which they happen. But how does an author arrive at a time and a place for her story? Do characters arrive first, bringing their times and spaces with them? Might particular spaces and times prompt an author to conjure certain characters? In a discussion I return to later, Jos Smith speaks of "place-making as a...form of identity construction." Admittedly he is referring to the identity of a community rather than a person, but the statement can hold for both. Finally, to what extent does a fictional account need to be anchored in real space and real time, and if the story is not entirely real in both respects, how imaginative can a writer be, as she conjures unreal space and unreal events in a real place.

What follows explores the answers to some of these questions as I arrive at them in Red Jacket. In fabulist or science fiction, writers can exercise a free hand as they conjure time and space. Their accountability to what is or has been, is far less, and the limitations on their imagination, fewer. In historical fiction, the writer's hands are more tightly tied, for she must be accurate in the account of what has been. Red Jacket is neither fabulist tale nor historical fiction. It is a made-up story, set at a time marked by events, some real and some imaginary, and set in places, some real and some imaginary. A note at the beginning of the book addresses the actual and the fictive with respect to both place and time. It explains that Mabuli, the West African country, does not exist, and that despite many similarities, St. Chris, though a West Indian island, is not a "thinly veiled" version of my native country, Jamaica.

Real time as I use it here means chronological time. It is not Aristotle's unity of time, nor the equivalent of actual time elapsed. The storyteller uses devices for making time real-apart from ticking clocks and calendars. These include celebrations, festivals, weather phenomena, newspaper accounts and journal entries, anything that has made a moment memorable. Real space is easy enough: it is actual physical space, Google-maps-verifiable place. Every moment in

\footnotetext{
${ }^{1}$ Smith, p. 76.

Cultural and Pedagogical Inquiry, Summer 2020, 12(1), pp. 281-295

ISSN 1916-3460 @ 2020 University of Alberta

http://ejournals.library.ualberta.ca/index.php/cpi/index
} 
a story represents a conjunction of space and time: real time and real space intersect, or real time and made-up space, or real space and made-up time. In discussing one, it is inevitable that the other be mentioned, so that the sections identified as concerning space and time below do not exclusively address one or the other, but are named according to emphasis.

\section{Section One: Real Space}

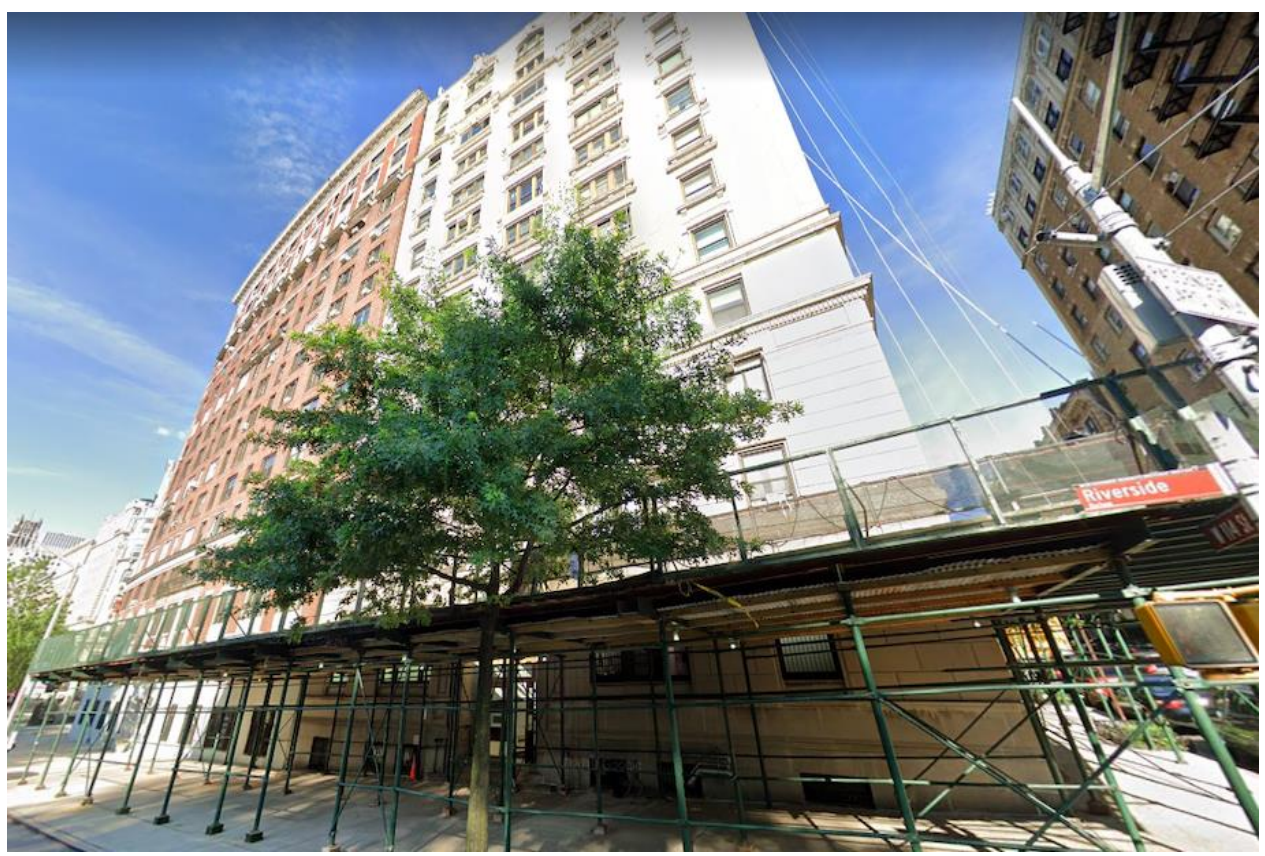

114 Riverside Drive, New York City (Photo @ Google Maps)

Red Jacket begins with the place and date on a letter, a marriage of space and time: 114 Riverside Drive/United States of America/July 18, 1960. The date (incomplete because Phyllis is just learning letter-writing) is real time, certainly; it has been and gone. And the place is real enough: I used to live there, and the building still stands (See photo). In narrative time, it marks the beginning of Grace's growing up, as imagined by Phyllis. Phyllis writes the letter right after she arrives in New York, having just given Grace up for adoption, so that moment also marks a new stage in Phyllis's growing up.

In 1960, I arrived in New York en route to college in Newton, Massachusetts, where I would spend the next three years. I spent summers at this address, in the city, as well as occasional holiday breaks. I knew the space well. It was a familiar location and so, for me, an apprentice novelist, a secure place to begin.

However, never mind that both are real, there's nothing special about the year or the address on Riverside Drive, except as they feature in the story. In contrast, some of the events in the novel occur in significant real places - and real times - a significance that obtains outside the novel and persists in the real world. Ironically, I have never visited any of these significant real spaces. They were serendipitous, sometimes virtual encounters that by some alchemy became 
integrated into the text, on occasion bringing stories with them. The fact that I included them, often describing them in considerable detail, must mean that at some point, I became bold enough to depart from spaces that I knew well, since these I did not know at all.

One of those real and unfamiliar places is the Fox Memorial Tiffany Window, in Newberry Hall, at the University of Michigan. Having graduated from U of T Grace goes almost immediately to the US, to Rackham Graduate School, at the University of Michigan in Ann Arbor. She's very unsettled. She's just had a big fuss with her mother, Phyllis, for which she thinks she is to blame. She has not been able to contact Phyllis to apologize because she has had to pack in a great hurry to get to Ann Arbor on time. She is therefore in bad emotional shape.

In the course of her four years in Toronto, she had not managed to find a suitable church to join and she now regrets not having stuck with "Beloved", a church with a Caribbean congregation to which she had gone for a while. She determines to find one in Ann Arbor, though she's not sure how to go about it.

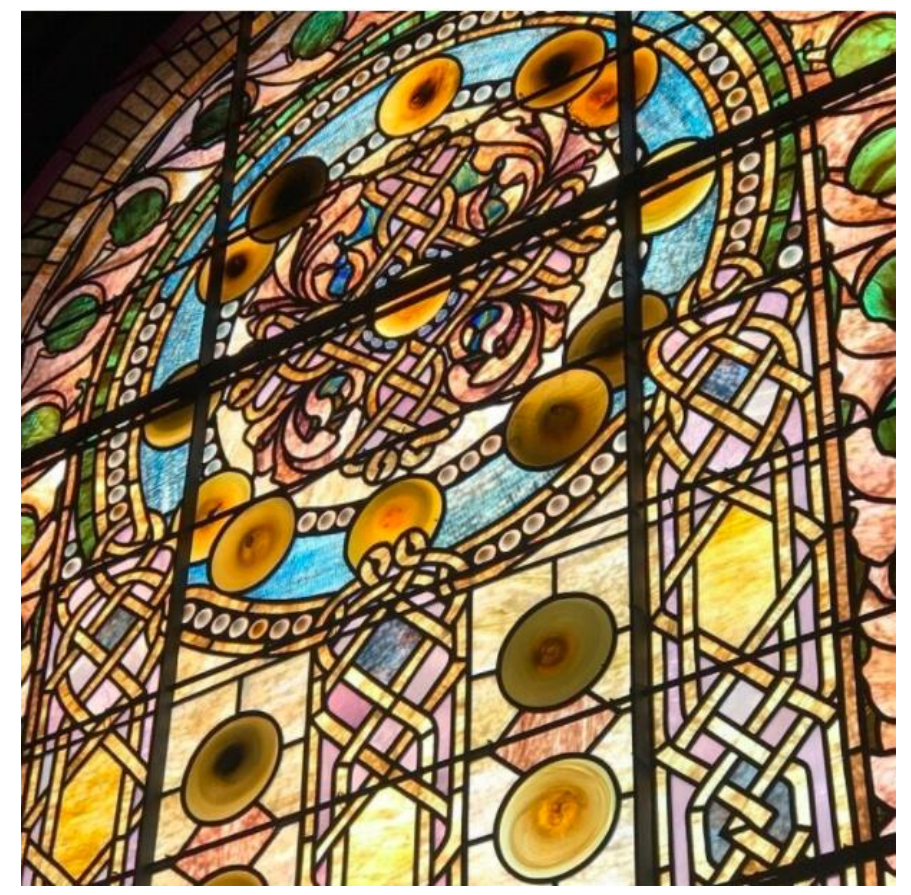

Fox Memorial Tiffany Window (Photo Courtesy U of Michigan)

The big stained-glass window in the Museum of Archaeology stops her like a slap the first Saturday. No glass window she has seen anywhere looks like it. At first, she sees only a shedding of soft tones, a gentle splashing of well-behaved hues playing into the room. When she steps forward to focus, she sees a royal purple frill outlining a huge arch and running all the way down the two sides and across the bottom of a large, long window. Inside the frill/is another border that resembles accordion pleats of thin brown louvres, or dark popsicle sticks ranged side by side. A vine bearing bright, round emerald leaves, or maybe fruit, each in 
a curled lilac nest, winds its way close to these edges. Some old, overripe balls of Seville oranges, greenish, dirty yellow, brown-and-gold, looking as though they are spoiling or spoiled, roll around in a bold blue circle at the top, and run down in two lines that lead from the blue circle above to the bottom. Everything lands in a leafy design below. Scrutinized, it's not so pretty, but altogether the colours and the design bloom soft rays on everything.

She can't stop gazing the day she finds it. For no reason, it brings back Wentley and rests it on her heart...

So, this is her church. She stops by almost every day, stares, considers, rails a little at Papa God. In time, she assembles a small group of four or five Caribbean folks who meet here once a week to meditate. (Mordecai, 2015, pp. 250-251)

It was a little unnerving when I discovered, after choosing the Tiffany window as Grace's worship space, that the Student Christian Association built Newberry Hall and that the Association held prayer meetings there at one time! ${ }^{2}$

I have never visited West Africa, so I have never seen the magnificent Bandiagara Escarpment (or Plateau) in the Dogon country of Mali. Over 200 kilometers long, it rises some 500 meters above sandy flats, its sandstone cliffs extending from south to northeast and constituting one of the most remarkable sites in Africa, so much so that it is included in UNESCO's Heritage List. As the UNESCO World Heritage entry describes it: "The Bandiagara site is an outstanding landscape of cliffs and sandy plateaux with some beautiful architecture (houses, granaries, altars, sanctuaries and Togu $\mathrm{Na}$, or communal meeting-places)." The citation points out that several ancient social traditions survive in the region, including masks, feasts, rituals, and ceremonies involving ancestor worship. It concludes: "The geological, archaeological and ethnological interest, together with the landscape, make the Bandiagara plateau one of West Africa's most impressive sites."3

In Red Jacket, the Centre where Jimmy Atule S. J. lives and administers the MATE project is not far from the Bandiagara Escarpment. Between the eleventh and sixteenth centuries, the Tellem, a people reputed to fly by some folk in Mali, even today, lived at the foot of the scarp, and in the cliff face. The Plateau has also hosted the Toloy and Dogon peoples, the Dogon being the present occupants. In Red Jacket, the Tellem appear in a (made-up) legend. Mabuli lore recounts how they may have helped to bring English — one of two European languages in Mabuli, the other being French - to the country. I discovered from maps that the Plateau was near to the location in which I had set Mabuli, and so introduced it into the story. The Dogon people I had heard of, but not the Tellem, who proved very useful in explaining the presence of English in a largely Francophone part of Africa. In this case, place arrived and brought story with it.

The landscape feature is in fact culturally, archeologically and historically significantand an example of the conjunction of real space and real time in the novel.

\footnotetext{
${ }^{2}$ It was also uncanny when a friend told me that while he was a student at Ann Arbor, he would pass by the Tiffany window from time to time and sit and contemplate.

${ }^{3}$ https://whc.unesco.org/en/list/516

Cultural and Pedagogical Inquiry, Summer 2020, 12(1), pp. 281-295

ISSN 1916-3460 (C) 2020 University of Alberta

http://ejournals.library.ualberta.ca/index.php/cpi/index
} 


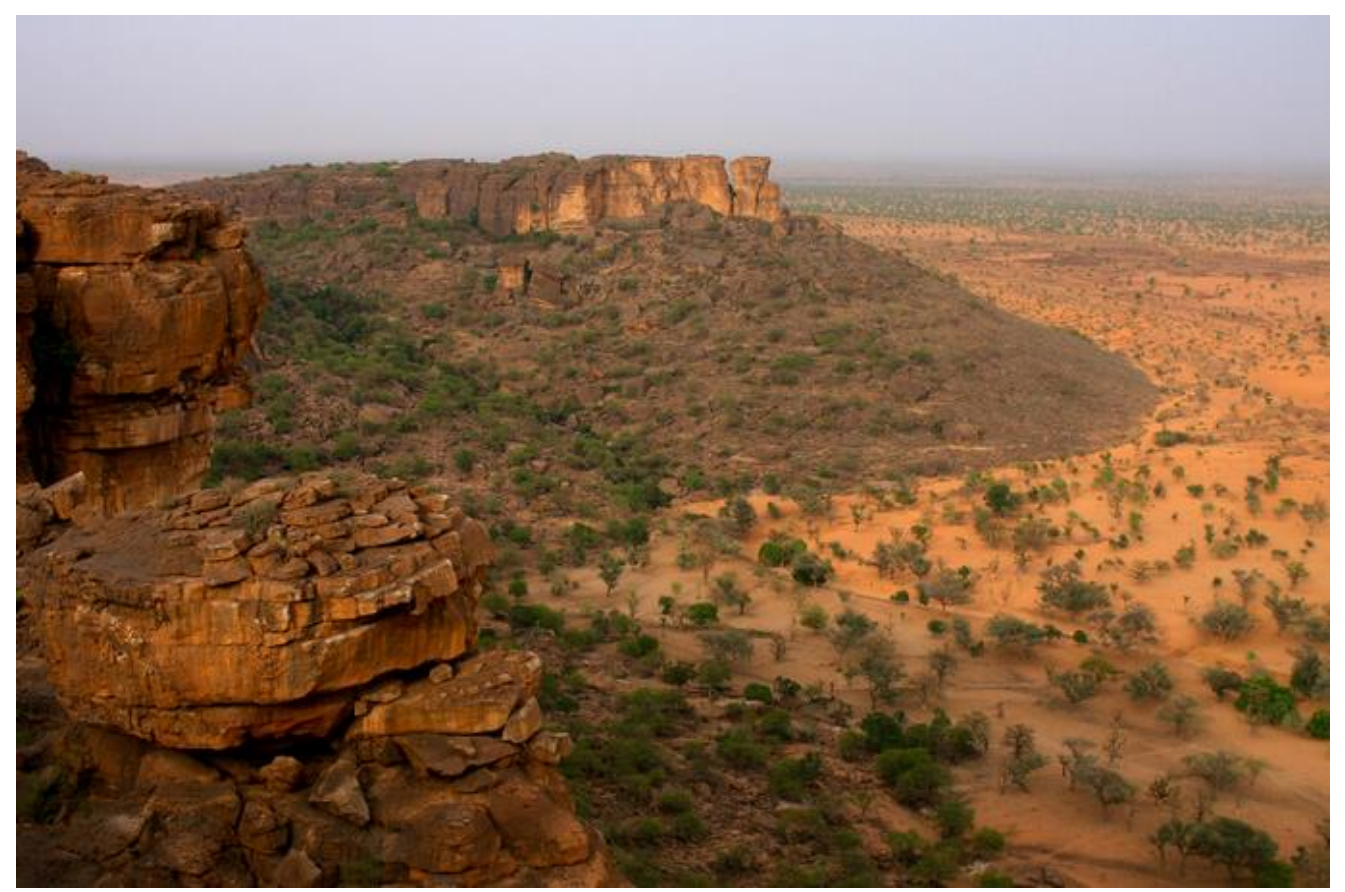

Bandiagara Escarpment by jzielcke (CC BY-NC 2.0) https://www.flickr.com/photos/jzielcke/10561816246/in/photostream/

What is achieved by anchoring the narrative in space (and, sometimes inevitably, concomitant time), as it exists and we have known it? It's hardly an irrelevant question at a point where publishers say that readers are no longer interested in fiction, that they'd rather read factual stories and historical accounts. Is it because the two, real space and real time, better persuade the reader to suspend disbelief? Assuming, of course, that these are stories that want to persuade the reader they are real, as distinct from fables, or science and speculative fiction. And if so, why, in our discussions of fiction, have we not talked more about space - and I might add, time?

"While characters and plot have been and are subject (sic) of countless philological studies," say Piatti et al., "the topic of space and place in literature is rather neglected.

Nevertheless, territorial and topographical aspects of literature have received renewed academic attention within the last decades." Piatti et al., all cartographers, suggest that in searching for ways of mapping stories and arriving at the value of such maps, "the horizon of a promising interdisciplinary research field - a future literary geography - becomes visible.” They go on to ask, "What happens when the 'literary world' (textual space) and the real world (geospace) meet or intersect?"- as they do in Red Jacket (Piatti et al., 2009, p. 182). How can that intersection be diagrammed?

These authors' preoccupations concern cartographic matters and how to retool the mapmaker's ways and means for the literary purpose. How does one diagram stories with 'real world counterparts', that is, stories set in existing regions, such as those sections of Red Jacket set in New York, Toronto, Warsaw (Ontario) and Ann Arbor, where streets and university 
quadrangles and buildings named in the novel, actually exist? They are also concerned about another question: How to diagram stories that combine real world with fictitious elements? Mabuli, the West African country in Red Jacket, is an example of the combination of real and fictive worlds since, though it is an invented country, it has an exact location so that natural and human geographic phenomena like the Bandiagara Escarpment, Gao, and the piste running across the Sahara figure in the text. Whatever obtains for that region as far as topography, vegetation, agriculture, occupations and so on, applies for Mabuli.

The cartographers propose setting, zone of action, projected space, markers and route as the five main categories that comprise fictional space. Whereas there are conventions for mapping setting, zone of action, markers and route, another challenge for literary geographers is how to map "projected space"; that is, how to set down and differentiate locations-towns, cities, savannahs, mountains - that enter the narrative in the thoughts and imaginings of characters. In evaluating possibilities with new media, for expressing so-called literary metaspace on interactive maps, they demonstrate the versatility of those technologies (Piatti et al., 2009, p. 182).

The authors finally describe a fascinating "current project, entitled 'A Literary Atlas of Europe." The project begins by examining the "literary permeation" of locations in Switzerland, Germany and the Czech Republic so as to determine the potential of this method, both for placing single texts and huge amounts of textual material. ${ }^{4}$ The three places are examined "within a time frame of about 250 years, from approximately 1750 to the present." Between 200 and 900 texts chosen for each of the three regions serve as a starting point for critics. "Through the interplay between these materials, the database, the mapping solution, the interpretations and comments, a prototype of a literary atlas will be provided." As a last step, literary scholars will analyze and comment on the resulting maps, and in this way start to write chapters presumably relating to each of these places, of a future literary atlas of Europe. "The idea is to develop methods which can be applied to any other geographical region and on any other selection of fictional texts" (Piatti et al., 2009, p. 193).

A literary geography like this will deal with a broad range of questions, some of them for the first time. "Are there still any geographic areas entirely undocumented in literature? How densely settled by fictional works is a particular space? How internationally occupied is it? Is the space inscribed almost exclusively by native authors? Under which conditions (political-historical not least) does the (imaginary) space of literature contract, and under which does it expand?" (Piatti et al., 2009, p. 193).

Such a literary map can establish how far afield a writer goes, in a single narrative or in that person's canon of narratives. Jane Austen does not go far. Mark Twain ventures all over. Red Jacket wanders over the Caribbean, North America, Europe and Africa. It would contribute to increasing the literary density of Toronto, New York, Ann Arbor, Haiti and Geneva - and might put Warsaw, Ontario, on the literary map! ${ }^{5}$ A map can also plot the spatial journeys that authors within a national canon make, over particular periods of time. Where do Canadian

\footnotetext{
${ }^{4}$ www.atlas-of-literature.eu When the essay was originally written, this project was relatively new. At the moment (June 2020) it appears to have stalled, the most recent post being dated 2015, with a comment on that post in February 2016. There is a 2019 copyright date on the website.

${ }^{5}$ A Google search did not turn up any short or long fiction set in Warsaw, ON.

Cultural and Pedagogical Inquiry, Summer 2020, 12(1), pp. 281-295

ISSN 1916-3460 @ 2020 University of Alberta

http://ejournals.library.ualberta.ca/index.php/cpi/index
} 
authors journey in their narratives? Did Canadian stories begin to stray to countries outside of Canada at a particular point in time? Where do those stories take the reader now ${ }^{6}$

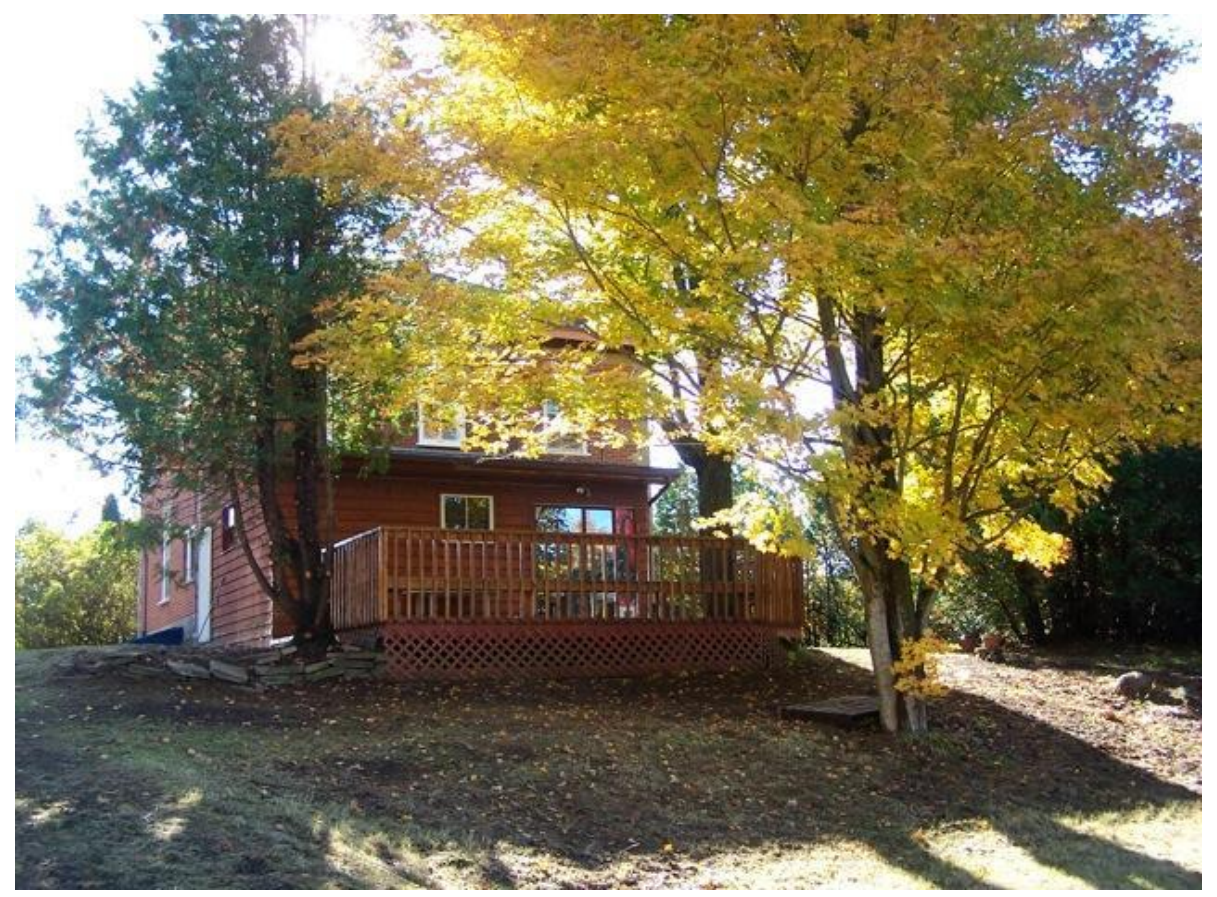

Farmhouse in Warsaw, Ontario (Photo @ Stephanie Martin)

Such a map must also be a useful tool for the individual author. The setting of a story is more than just that: it is a key to the type or types of characters in the story. A literary map can tell an author how large or small his imaginative world is, or how consistently she is preoccupied with a particular type of place, or with particular kinds of people.

In 2015, the nascent discipline had come far enough that a journal called Literary Geographies appeared online. The journal features work combining topics and methods from literary studies, cultural geography, cartography, and spatial theory. Neal Alexander, in the first of a number of planned short "position papers" on "key terms and concepts for literary geography", puts the new discipline into perspective: "Over the past two decades, geographers have become increasingly sophisticated readers of literary texts... Similarly, literary critics are more than ever aware that if they are to examine fully what Edward Said calls the 'geographical articulations' of literary texts, it is essential to read the work of actual geographers (Said, 1993, p. 61 in Alexander, 2015, p. 4)." They go on to say that: "It is as a forum for such innovative, exploratory, and interdisciplinary research that Literary Geographies has been established..."8

\footnotetext{
${ }^{6}$ The website notes that "Literary Atlas of Europe" is currently under development at the Institute of Cartography and Geoinformation, ETH Zurich." (Accessed 13 January 2016).

${ }^{7}$ Neal Alexander, "On Literary Geography" in Thinking Space series in Literary Geographies, 1(1), 2015, p. 4. (Accessed 13 January 2016).

${ }^{8}$ Ibid.
}

Cultural and Pedagogical Inquiry, Summer 2020, 12(1), pp. 281-295

ISSN 1916-3460 @ 2020 University of Alberta http://ejournals.library.ualberta.ca/index.php/cpi/index 
Writing in Literary Geographies, Jos Smith looks closely at smaller geographic spaces. Exploring Heidegger's idea of earth as distinct from world, he recounts a couple of intriguing stories first told by other authors. One is Hebridean islander Alastair McIntosh's account, in his book, Soil and Soul, of a thirteen-year battle between dwellers on the Isle of Harris, aided by various charitable NGOs, and lawyers of Lafarge Redland Aggregates, a company proposing to extract between 10 and 20 million tonnes each year out of a mountain called Roineabhal, thus leaving a hole in the side of the mountain that would be the largest of its kind in the world. (McIntosh, 2001, p. 148 in Smith, 2015, p. 74). Another concerns the efforts of people on the island of Eigg to buy back their island from an absentee landlord and make it into the first autonomously owned Scottish island. Smith says, "In both instances the 'consciousness raising' that the communities undergo is a quite practical and creative sense of place-making as a community-driven, bottom-up form of identity construction" (Smith, 2015, p. 76). There is a noteworthy Canadian connection in this latter case. ${ }^{9}$

Taking my cue from such attention to small spaces, and perhaps pushing the idea of community-driven place-making as a form of identity construction to the extreme, I focus on a small item in teenage Phyllis's room. When she tells Grace about Ralston raping her, she says he does it in her room on a mat she made. Her account is a terrifying tiny bit of literary geography, but more to the point, the map, an imaginary construct, constitutes in itself a knitting together of real temporal events: West Indian immigration to the UK, importation of East Indian indentured labourers to the West Indies, and World War II.

All of a sudden I smell somebody beside me stink of beer, cigarettes, and sweat. I feel the bed slope as he put his weight on it. I never even have time to ask him what he is doing in my room, and he never even say 'dog' to me, just shove me onto the rug on the floor beside the bed. To this day I don't know why he never just do it on the bed. I make that rug myself when I was eight. I walk all up and down Hector's Castle begging people for cloth, and the rug remind me of so many people: Ma Phelps up Loomy Road that give me a piece of tartan, say her sister send it from Scotland for her eightieth birthday; Mrs. Budhai that give me a scrap of green silk, a bit of the sari her grandmother wear when she step off the boat from India; Sister Mingo that give me a strip of heavy navy blue cloth her mother use to cover the windows in wartime, still strong and sound as a drum. (Mordecai, 2015, pp. 379-380)

This, perhaps, bizarre intersection of fictional space and real time makes an ideal transition to discussing real time in the novel.

\footnotetext{
9 “...perhaps one of the most surprising aspects of the fight for the mountain is the visit from Nova Scotia in Canada of the Mi'Kmaq Warrior Chief Sulian Stone Eagle Herney in 1994. He was invited by Mclntosh and the people of Harris to come and give testimony at the British Government's public inquiry into the super-quarry. The connections are multiple and quite curious. Stone Eagle had been fighting the Kelly Rock Co. in Canada who had, since 1989, been attempting to site a large quarry in the side of a mountain in the Gulf of St. Lawrence deemed sacred to the Mi'Kmaq people. The mountain is situated in an area very near the coastal edge of that geological fault (the Cabot Fault/the Great Glen Fault) shared by Canada and Scotland" (Smith, 2015, p. 75). (Accessed 13 January 2016).
}

Cultural and Pedagogical Inquiry, Summer 2020, 12(1), pp. 281-295

ISSN 1916-3460 @ 2020 University of Alberta

http://ejournals.library.ualberta.ca/index.php/cpi/index 


\section{Section Two: Real Time}

Events playing out in a setting arrest diachronic time and demand synchronic accounts. Simultaneity, things happening at once, can only occur by taking account of place. Weather is a phenomenon that depends on both the synchronic and diachronic, both space and time. It is synchronic, blossoming in a location, and diachronic as well, for it progresses. Where then to put weather in this discussion? What matters more where weather is concerned, where, or when? How to determine the emphasis? Both space and time seem to enter equally into constructing weather. However, more than just contributing to making it, time can determine nuances of weather in the same place. The cooling effects of evening breezes, say, on a hot day, convectional rain in the afternoon, and the rain that comes with the waxing moon can all further regulate weather. By this casuistry, I decided to consider weather events as part of narrative time. In addition, many folk traditions have reckoned time according to significant weather events: "the last big hurricane," "the storm that blew down all the bananas," "the three years of drought," etc.

There are three (or more accurately, three and a scrap) threads of time running through Red Jacket. One thread takes place in the recent past beginning in 1993, when Grace and Mark, the Chancellor of UA, meet at a weekend workshop in Cambridge, Massachusetts, and have their fling, and ending in the first weekend of November 1998, when Grace goes back to St. Chris to receive an award from UA, at their graduation ceremony; a second thread follows Grace from the moment of her conception, through her growing up, joining the first thread when she arrives in Mabuli, pregnant; the third thread follows Jimmy from his being a baby, through his growing up, to his meeting Grace in Mabuli. The scrap of thread involves a flashback that intrudes into the middle of the story: it tells what happens to Ralston, Phyllis's half-brother and Grace's father.

Space-time actualizes the occasion when Grace first phones Phyllis. The call is critical to the story, but the weather (as I have said, a function of space-time), is significant in itself.

October twenty-first, Sunday. It's twenty-four degrees Celsius outside, some kind of record, according to the news. Rugs of leaves in love-bush colours curl over themselves. From a payphone near a window upstairs in Robarts Library, Grace looks at people scooting about on bicycles and on foot, in shorts and T-shirts. Lord! It's not that hot! Still, better a bright, warm day to do what she was about to do. After hours of debating about whether, when and how soon to call her birth mother, she'd decided the phone conversation was inevitable and so better done sooner than later.

"May I speak to Phyllis, please?"

"This is she. To whom am I speaking?"

"It's Grace. Grace Carpenter."

"Grace? Grace! Can you hold one minute, please?"

"Yes, of course." 
A few seconds' silence during which Grace recalls Phyllis's letter in response to hers, a kind of proper, stiff writing, nothing as simple and forthright as the letters she'd written to her as a teenager. (Mordecai, 2015, p. 226)

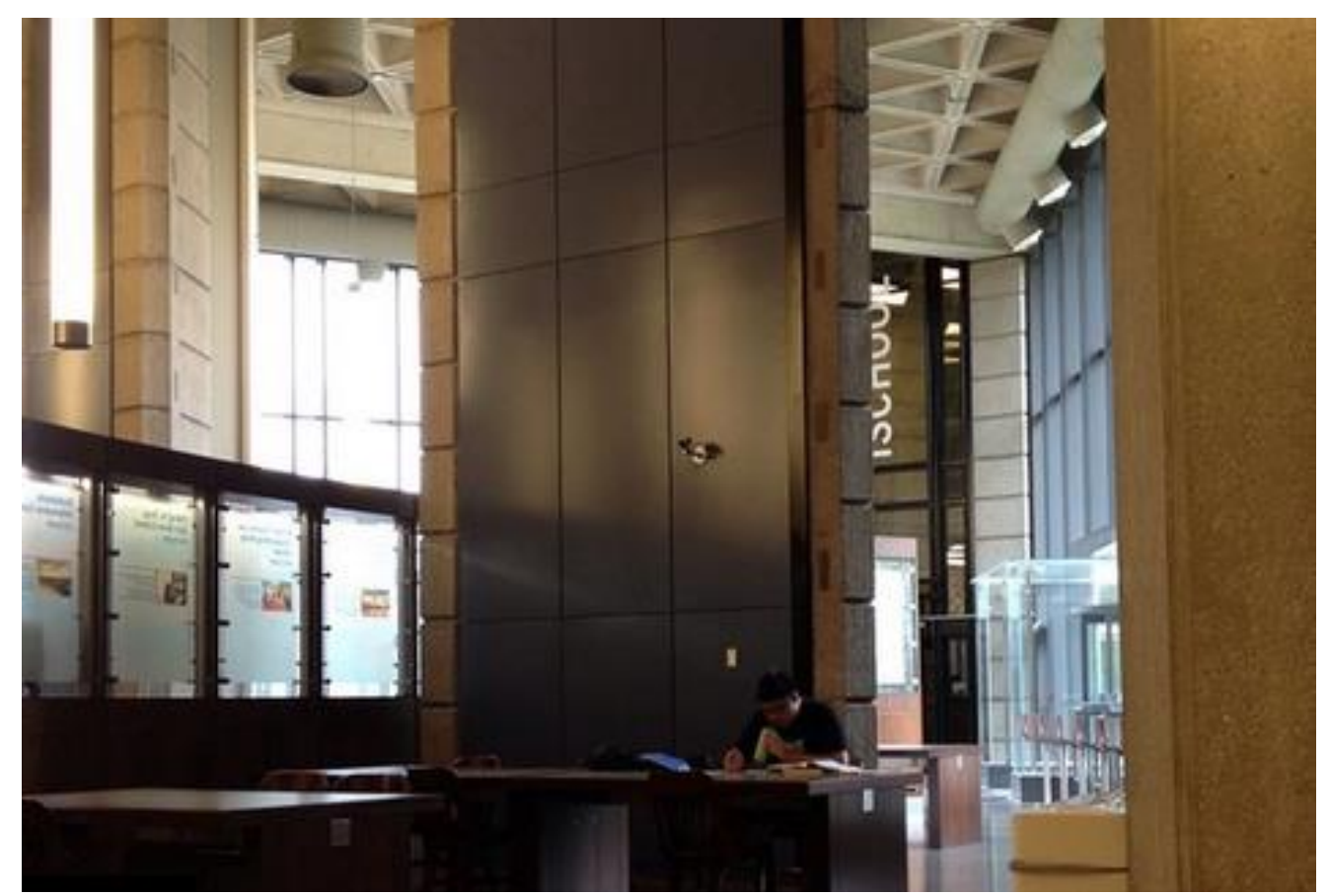

“OIISDP-2013” (Robarts Library, University of Toronto) by tsuomela (CC BY-NC 2.0) https://ccsearch.creativecommons.org/photos/32f82ec9-8f95-4454-a479-adc53a06f1fa

The specific setting, Robarts Library, is not especially significant. It's a university library, albeit impressive in a stark, overbearing way for its Brutalist architecture, but it might easily have been some other library at the University. Its location in Toronto, however, is important. On that date the temperature did in fact achieve a record high for temperatures in the city, at the time, a record that remained until 2007. What makes the date forcefully real and not just another October day is an aspect of weather and so, temporal and spatial. 


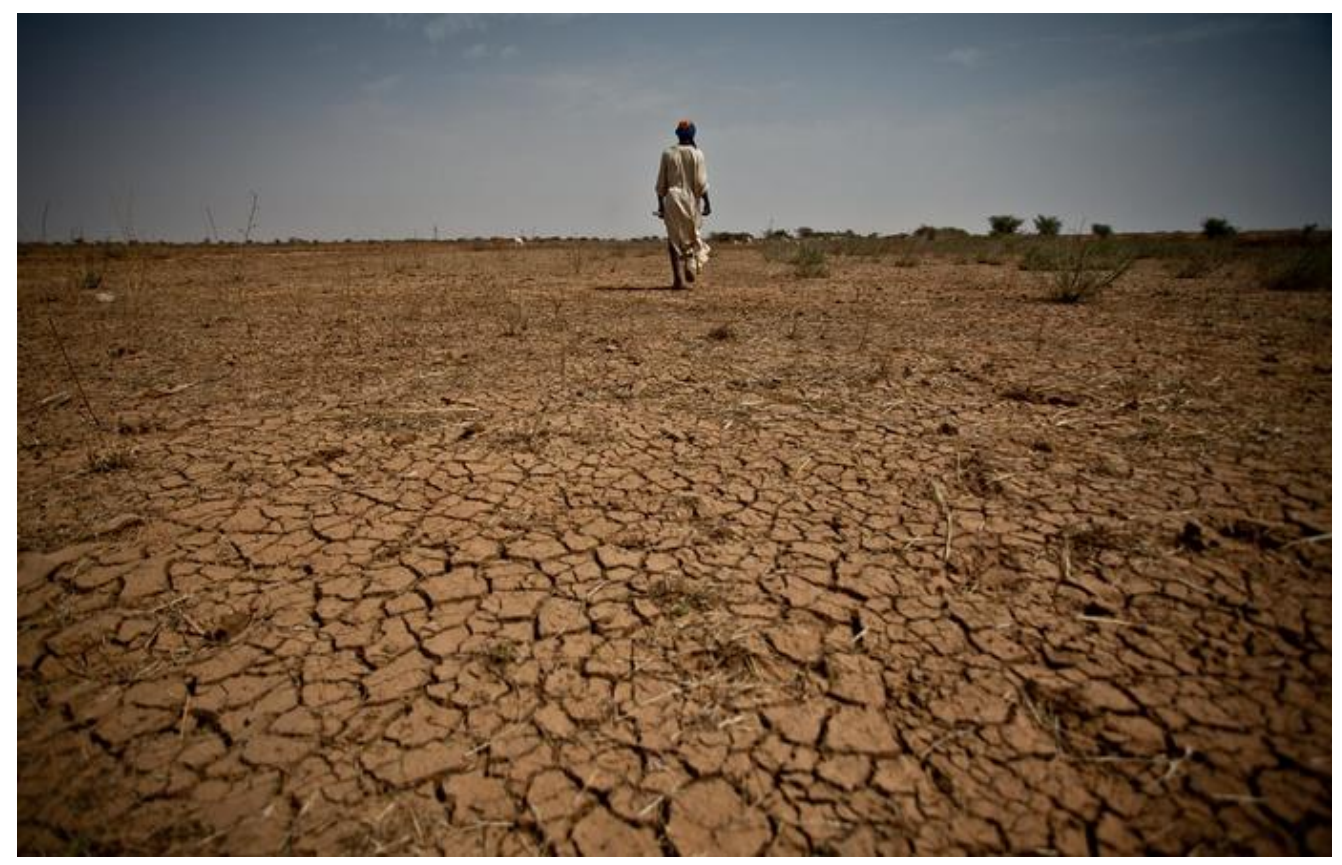

"Arid soils in Mauritania" by Oxfam International (CC BY-NC 2.0)

https://www.flickr.com/photos/8470194@N02/6909399053

There are several other examples in Red Jacket in which real space and real time are tied by weather, though in these cases the events are all catastrophic. When Jimmy Atule enters the seminary, the Sahel has for several years been devastated by severe, unremitting drought. When he is ordained in Mabuli on the feast of Notre Dame de Douleurs, September 15, 1988 - a real feast day in the Catholic Church - there are floods in Burkina Faso. Also, his friends from St. Chris cannot come to his ordination, because Hurricane Gilbert has just swept through the Caribbean, grounding all air traffic. The descriptions of these events in the Caribbean and West Africa, which actually took place at those precise times, renders those places and events special as real time_real space phenomena.

If Jimmy's story recounts natural catastrophes that did in fact take place, Grace's section introduces geo-political disruptions. As I've said, the novel begins with the place (NYC) and date (18 July 1960) recorded on Phyllis's first letter to Grace. I use letter writing in the earlier chapters of Red Jacket to establish elapsing time. As Grace grows up, going to school in Wentley Park and then in Queenstown, there is a parallel, imagined account of her maturing in letters that Phyllis writes, one a year, on her birthday, ending with one written in 1978 when mother and daughter finally connect. At one point, there were nineteen letters from Phyllis to Grace in the MS: the letter in 1960 with which the book begins, and one for each of the years until nineteen seventy-eight. However, my editor and I decided that so many would weigh too heavily on the story. In the event, eleven of Phyllis's letters appear in the novel and they refer to many of the geo-political events of the sixties: the marches in Selma, the riots in Watts, the Vietnam War, and Richard Nixon's election, all find their way into Phyllis's letters. Why would an ignorant adolescent growing up with an aged and infirm grandmother in New York City notice such things? Phyllis explains to her daughter in her 1966 letter: "Sister say take a interest in what 
going on in the world so here is the news" (Mordecai, 2015, p. 24). Indeed, in a letter in the early seventies, Phyllis explains why she stops giving Grace 'the news'. The letter is dated 25 March 1972, and says

I am sorry I have not been good at the news in my last letters. It's always the same thing, over and over, and most of it bad. The one good thing is that black people seem to be making some progress in getting their rights at last. I don't want to talk too soon, but we are all hoping and praying. (Mordecai, 2015, p. 53)

It is HIV/AIDS that brings Jimmy and Grace together, a disease that is arguably a spatial, geo-political as well as through-time event. In early 1982, when the disease begins to spread in North America, Grace encounters it while volunteering at Myrta's Home in Chicago. Jimmy meets it in 1988, when one of his brothers-in-law dies from the disease. The timing of both accounts is accurate for the identification and early spread of the disease in the US, and its sweep across Sub-Saharan Africa. Similarly, in January 1984, when Grace meets Charlie and he explains that he is working on discovering whether HIV/AIDS originated in Haiti, this is correct in historical time, as is the description of the unrest in Haiti occasioned by Fr. Aristide's Ti Legliz. Perhaps the final historical anchor for the book is Jimmy's prescient fit in which he foresees the Rwandan genocide which takes place in a 100-day period from April 7 to mid-July 1994. His fit occurs in January of that year.

Grace is born on March $25^{\text {th }}$ of 1960 , so her life as described in the novel spans 38 years, 1960 to 1998 - not including her nine months in utero, for we know when Phyllis gets pregnant (from the 'scrap' of a narrative thread), though we do not know that it is with Grace. If we borrow the literary geographers' notion of projected space and apply it to time, the projected time in the novel reaches back, via Gramps' accounts, to the very real event of the Second World War, and still further back, via Miss Carmen's stories of growing up in the early twentieth century and going with her mother to Marcus Garvey's (also real) consciousness-raising entertainments in Jamaica. Jimmy recounts his grandmother Mapome's story about Atunkle, her great-great-grandfather, who meets Napoleon when he visits Egypt in 1798. Napoleon's visit actually took place, though Atunkle is imagined. Indeed, the reader goes back, via Jimmy's recounting, to the Tellem people who lived on the Bandiagara Escarpment in Mali in the fifteenth century!

The note at the beginning of Red Jacket has this to say about time: "I have tampered with history in moving the first Blue Jays game from April 7, 1977 to April 7, 1978, but the day of that game was indeed a day of snow and freezing temperatures. I have been true to most other events of climate and human history in North America" (Mordecai, 2015, p. 8). The first Blue Jays game is therefore the only real event with an inaccurate date in the novel. The game is important to the plot. Events in the second academic year of Grace's undergraduate study at U of T build towards the night of April 7, 1978, a night Grace dreads, because she is to make a panel presentation for which she feels unprepared and inadequate; the game gets her off the hook. When I discovered I had mixed up the dates, there was nothing to be done but go with the 'error', and explain it in a note, in much the same way a good anthologist presenting, say, a regional collection in which an important writer is missing, explains the omission in the introduction. Things had gone too far with the story and the Blue Jays could not be done without!

Cultural and Pedagogical Inquiry, Summer 2020, 12(1), pp. 281-295

ISSN 1916-3460 @ 2020 University of Alberta

http://ejournals.library.ualberta.ca/index.php/cpi/index 
There was one last challenge, also of time's making. If places in Red Jacket arrived, bringing story with them, the approaching year 2000 demanded that it be included in the story. It dawned on me in the course of writing, as the novel drifted towards its climax in 1998, that Y2K loomed, periphrastic, on the horizon. I had to take account of that event, inevitable of course, and, at the time, ominous in many respects.

\section{Conclusion}

One of the (very few) critical reviews of Red Jacket comments on how detailed it is. These facts of history, weather, vegetation, topography, habits and customs perhaps spring in different ways from my insecurity as an apprentice novelist. I also had an experience with a good friend - poet, short-story writer, historian, and cultural theorist, the late Kamau Brathwaite - that put me on my guard. I think I may just have started writing Red Jacket when Kamau took issue with one of the poems, in my third collection of poetry, Certifiable (Goose Lane Editions, 2001) because it described the "Mona moon" as rising out of the sea. As anyone who has had the great fortune to see it can attest, as observed from the Jamaica campus of the University of the West Indies, the Mona moon rises over Long Mountain. I knew this, of course, but I needed 'sea' for the rhyme.

Often, a debut novel is a quasi-biographical account of the life of the apprentice novelist, and so has a kind of dim 'reality' in that respect. Apart from coming to North America (the USA) on a scholarship for an undergraduate education, and apart from our both residing for some time at 114 Riverside Drive, Grace's story has no real-space connection with mine and our experiences differ widely. Our stories do not overlap in time, either. When Grace is born, I am about to begin my undergraduate education, a world-weary woman of seventeen!

Mabuli and St. Chris are both invented countries, and to some extent invented for the same reason: where places are the products of fancy, they need only be accountable to the imagination. However, by precisely locating the Caribbean island and the small West African country, I attempt to buy the reader's credulity. Faithful accounts of weather in all the places in the world, where the protagonists wander, attempt to do the same thing. In the writing, space became more than geographic space, as we have seen; it became socio-historical, sociocultural — and socio-linguistic ${ }^{10}$ — space as well, with weather in a warming world a pre-eminent feature of socio-history. In other words, history, time, and its theatre of performance, space, prove indivisible.

${ }^{10}$ I discuss the sociolinguistic exigencies in Red Jacket in another paper. 


\section{References}

Alexander, Neal. “On Literary Geography”. Literary Geographies, 1(1), 2015, pp. 3-6. Online. (Accessed 4-5 January 2016).

Kennedy, Valerie. Edward Said: A Critical Introduction. Oxford, UK: Malden, MA: Polity Press, 2000. Print.

Mordecai, Pamela. Red Jacket. Toronto: Thomas Allen Publishers, 2015. Print.

Mordecai, Martin and Mordecai, Pamela. Culture and Customs of Jamaica. CT: Greenwood Press, 2001. Print.

Paul, Lissa. "The Man in Black on the Woman in White: Ted Hughes on Emily Dickinson", Cercles: Revue plus disciplinaires du monde Anglophon. <www.Circles.com>. 2/2001. Print.

Piatti, Barbara, Bär, Hans Rudolf, Reusche, Anne-Kathrin et al. "Mapping Literature: Towards a Geography of Fiction", Art and Cartography. Eds. William Cartright, Georg Gartner, Antje Lehn. Springer-Verlag, 2009. Print. (Accessed 4-5 January 2016). http://www.literaturatlas.eu/files/2012/01/Piatti2008_ArtAndCartography_Springer.pdf

Smith, Jos. "'Lithogenesis': Towards a (Geo)Poetics of Place”. Literary Geographies, 1(1), 2015, pp. 62-78. (Accessed 4-5 January 2016). 